\title{
Prevalence of enterotoxins $B$ and $C$ in clinical isolates of Staphylococcus aureus from Southwest of Iran
}

\author{
Sajad Ababaf', Abdolmajid Ghasemian', Hossein Motamedi², Farshad Nojoomi ${ }^{*}$ \\ ${ }^{1}$ Microbiology Department, Faculty of Medicine, AJA University of Medical Sciences, Tehran, Iran \\ ${ }^{2}$ Biology department, Faculty of science, Shahid Chamran University of Ahvaz, Ahvaz, Iran
}

\section{*Correspondence to \\ Farshad Nojoomi, Email: fnojoomi2@gmail.com}

Received 10 February 2018 Accepted 28 April 2018 Published online 2 May 2018

Keywords: Staphylococcus aureus, Enterotoxin, Food poisoning

\section{Citation: Ababaf}

S, Ghasemian A, Motamedi $\mathrm{H}$, Nojoomi

F. Prevalence of enterotoxins B and C in clinical isolates of Staphylococcus aureus from Southwest of Iran. Immunopathol Persa. 2018;4(2):e24 DOI:10.15171/ ipp.2018.24.

\begin{abstract}
Introduction: Staphylococcus aureus enterotoxins play an important role in the incidence of food poisoning and various other syndromes are occurred such as staphylococcal scalded skin syndrome and toxic shock syndrome.

Objectives: The purpose of the present study was to investigate the frequency of enterotoxin B and C genes among $S$. aureus isolates from clinical samples obtained from inpatients of a hospital by polymerase chain reaction (PCR).

Materials and Methods: This cross-sectional study conducted during the period July to December 2015 Clinical samples including blood, urine, wounds and nasal mucosa samples were collected from a hospital in Ahvaz, southwest of Iran and screened for $S$. aureus strains by several phenotypic and biochemical tests. A total of 132 clinical samples were collected from which 60 samples were infected with the $S$. aureus strains. Then PCR assay was carried out to determine the entB and entC genes prevalence among these isolates.

Results: Molecular analysis revealed that only $8(13.3 \%)$ isolates harbored the entB and/or entC genes. Five strains $(8.3 \%)$ contained only entB gene, 2 strains $(3.3 \%)$ contained entC gene and only one strain $(1.7 \%)$ was simultaneously positive for both ent $B$ and ent $C$ genes. There was no significant difference among various age groups regarding enterotoxin genes $(P=0.551)$.

Conclusion: These results demonstrated that enterotoxin-producing strains have a relatively low incidence in clinical samples in understudy hospital, but monitoring of their prevalence is necessary in regular screening programs in order to find the possible increase in their prevalence and prevention of their outcomes.
\end{abstract}

\section{Introduction}

Staphylococcus aureus strains play an important role in the incidence of clinical infections and food poisoning, as far as these microorganisms are introduced to the second or third cause of food poisoning (1). Virulence factors of $S$. aureus are exotoxins, surface proteins, extracellular enzymes and polysaccharide capsule (2). On the other hand, one of the most important pathogenic factors of this bacterium is enterotoxins family (3). Staphylococcal enterotoxins (SEs) are proteins with $26-29 \mathrm{kDa}$ molecular weights that are heat-stable and resistant to pepsin digestion and thus can cause gastrointestinal disease and food poisoning (4). SEs and toxic shock syndrome toxin-1 (TSST-1) are super-antigens that mean they can activate a large population of $\mathrm{T}$ helper lymphocytes $\left(\mathrm{CD}_{4}^{+}\right)$leading remarkable cytokine secretion, immune system disorders and even death (5). Each of SEs do this by non-specific binding to a portion of class II

\begin{abstract}
Key point
To investigate the frequency of enterotoxin B and C genes among S. aureus isolates from clinical samples obtained from in-patients of a hospital, we found that enterotoxin-producing strains have a relatively low incidence in clinical samples in a hospital of Ahvaz. However, monitoring of their prevalence is necessary in regular screening programs in order to find the possible increase in their prevalence and prevention of their outcomes.
\end{abstract}

MHC (major histocompatibility complex), for example staphylococcal enterotoxin $\mathrm{B}$ (SEB) bind to the alpha chain whereas enterotoxin $\mathrm{E}$ (SEE) bind to the beta chain of the class II MHC molecule $(6,7)$. Today molecular methods, including polymerase chain reaction (PCR) and multiplex PCR as well as immunological techniques are used to identify enterotoxins-encoding $S$. aureus $(8,9)$. Usually, enterotoxins-encoding genes are located on transposable genetic elements such as plasmids, prophages or

Copyright $\odot 2018$ The Author(s); Published by Nickan Research Institute. This is an open-access article distributed under the terms of the Creative Commons Attribution License (http://creativecommons.org/licenses/by/4.0), which permits unrestricted use, distribution, and reproduction in any medium, provided the original work is properly cited. 
pathogenicity islands (10). Totally, enterotoxins family is consisted of 20 members that based on their biological function and serological characteristics are classified into two subfamilies of classic enterotoxins (staphylococcal enterotoxins $\mathrm{A}$ and $\mathrm{E}$ [SEA-SEE]) and new enterotoxins (staphylococcal enterotoxins G-U [SEG-SEU]) $(11,12)$. It has been proved by many studies that not all of these enterotoxins cause food poisoning. SEA mostly causes $S$. aureus related-food poisoning compared to other enterotoxins (13). SEB while is related to food poisoning, is known as a bioterrorism agent (14). Additionally, SEC that is the third discovered enterotoxin, usually encoded by invasive $S$. aureus isolates, especially methicillin resistant S. aureus (MRSA) and is one of the main pollutants in milk that enable causes economic losses in the dairy industry $(15,16)$.

\section{Objectives}

The aim of the present study is to investigate the frequency of enterotoxin B and C-encoding S. aureus isolated from clinical samples by PCR.

\section{Materials and Methods}

Clinical samples including blood, urine, wounds and nasal mucosa samples $(5 \mathrm{~mL}$ for liquids and a sterile swab for wound and nasal mucosa) were collected during July to December 2015 from a hospital in Ahvaz, southwest of Iran. These samples were obtained from all patients referred to the pathology laboratory of the mentioned hospital. The bacterial isolates were identified based on several phenotypic and biochemical tests, including gram staining, catalase and coagulase analysis, growth on Mannitol salt agar (MSA) medium and susceptibility to furazolidone and resistance to bacitracin.

In order to screening for the presence of ent $\mathrm{B}$ and ent $\mathrm{C}$ genes, PCR assay was performed. DNA was extracted by boiling a single colony of $S$. aureus was dissolved in $200 \mu \mathrm{L}$ milli-Q water and heated at $100^{\circ} \mathrm{C}$ for 15 minutes. Then the sample was centrifuged at $5000 \mathrm{rpm}$ for 1 minute and the supernatant (containing DNA) was transferred to another Eppendorf tube. Cold ethanol 99\% (Merck, Germany) was added to this supernatant $(2.5 \mathrm{~V} / \mathrm{V})$ and stored at $-22^{\circ} \mathrm{C}$ for 1 hour. Following centrifugation at $13000 \mathrm{rpm}$ for 10 minutes the supernatant was discarded and the sediment as template DNA was dissolved in $50 \mu \mathrm{L}$ milli-Q water and stored at $-22^{\circ} \mathrm{C}$.

PCR reaction was carried out by specific primers for ent $B$ and ent $C$ genes (Table 1 ) in the $25 \mu \mathrm{L}$ reaction mixture contained $12.5 \mu \mathrm{L}$ of $2 x$ PCR Master Mix Red (Ampliqon,
Denmark), 10 pmol of each primer, $1 \mu \mathrm{L}$ of template DNA and $10 \mu \mathrm{L}$ of milli-Q water. Concentration of $\mathrm{MgCl}_{2}$ was $1.5 \mathrm{mM}$. The oligonucleotide primers for amplification ent $B$ and ent $C$ genes were selected based on the study of Mehrotra et al (17). PCR reaction was carried out by an initial denaturation step at $94^{\circ} \mathrm{C}$ for 5 minutes, 35 cycles each consisting of denaturation at $94^{\circ} \mathrm{C}$ for $2 \mathrm{~min}$, annealing at $58^{\circ} \mathrm{C}$ for 2 minutes, and extension at $72^{\circ} \mathrm{C}$ for 1 minute followed by a final extension step at $72^{\circ} \mathrm{C}$ for 7 minutes in a thermal cycler (Bio-Rad USA). The amplified product was confirmed by electrophoresis in $1.5 \%$ agarose gel for 45 minutes at $80 \mathrm{~V}$ and documented by UVI gel doc system.

\section{Ethical issues}

The research followed the tenets of the Declaration of Helsinki. Consent for the study had been taken. The ethical committee of AJA University of Medical Sciences, Faculty of Medicine approved the research.

\section{Statistical analysis}

The obtained data were analyzed by SPSS software (version 22) through chi-square method with 95\% confidence interval $(P<0.05)$. The $t$ test and ANOVA tests were performed considering $95 \% \mathrm{CI}$ and $P$ value $<0.05$ as a significant result.

\section{Results}

In this research, 132 clinical samples were obtained from the pathology laboratory of a hospital that among them 60 (40.5\%) S. aureus strains were detected after phenotypic and biochemical analysis.

These samples were from blood $(16,26.7 \%)$, urine (22, $36.7 \%)$, wounds $(8,13.3 \%)$ and nasal mucosa $(14,23.3 \%)$. From these samples, $78.3 \%$ were from men and $21.7 \%$ were from women. Also maximum $S$. aureus infection was in the age range of 21 to 30 years (Table 2).

The results of PCR assay indicated that 8 (13.3\%) of isolates were harbored with entB and/ or entC genes among them 5 strains (8.3\%) contained only entB gene, 2 strains (3.3\%) contained only entC gene and only one strain (1.7\%) were positive for both entB and ent $C$ genes. As depicted in Figure 1, strains of related by column 5 and 6 containing ent $B$. From the total of 8 ent $B$ and ent $C$-encoding $S$. aureus strains, maximum frequency belonged to urine by 4 strains (50\%). Also, their number in men was more than women (5 to 3 strains). Related data by 8 entB and entC-encoding S. aureus strains are summarized in Table 3.

Table 1. Nucleotide sequences, locations in genes and sizes of PCR products for ent $B$ \& ent $C$ genes-specific primers

\begin{tabular}{lllll}
\hline Gene & Primer & Oligonucleotide sequence $\left.\mathbf{( 5}^{\prime} \mathbf{- 3} \mathbf{3}^{\prime}\right)$ & Location within gene & Size of amplified product (bp) \\
\hline \multirow{2}{*}{ entB } & GSEBR-1 & GTATGGTGGTGTAACTGAGC & $666-685$ & 164 \\
& GSEBR-2 & CCAAATAGTGACGAGTTAGG & $810-829$ & \multirow{2}{*}{ entC } \\
& GSECR-1 & AGATGAAGTAGTTGATGTGTATGG & $432-455$ & 851 \\
\hline
\end{tabular}


Table 2. Number and frequency (\%) of clinical samples infected to Staphylococcus aureus based on age range

\begin{tabular}{lll}
\hline Age range & Number & \% \\
\hline 20 years and under & 14 & 23.3 \\
$21-30$ years & 19 & 31.7 \\
$31-40$ years & 11 & 18.3 \\
$41-50$ years & 9 & 15.0 \\
Over 50 years & 7 & 11.7 \\
Total & 60 & 100 \\
\hline
\end{tabular}

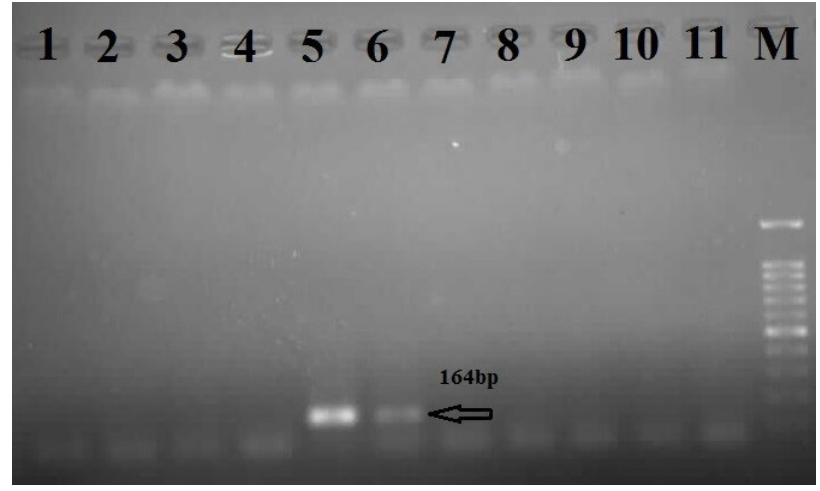

Figure 1. Electrophoresis patterns showing PCR amplification products for the Staphylococcal entB and entC.

Lane M: DNA Ladder (100 bp). Lanes 1-4 and 7-11: negative sample ( $S$. aureus with no entB \& ent $C$ genes). Lanes 5-6: related to entBencoding $S$. aureus.

\section{Discussion}

As SEs play a major role in pathogenesis of this agent and determining of the prevalence of $S$. aureus strains encoding these toxins is of great importance in order to control of its food poisoning. Identification of these strains is based on both molecular and immunological methods $(18,19)$. Advantage of molecular methods than immunological methods (such as ELISA and radioimmunoassay) is that in the first case, enterotoxin genes expression is not necessary and strains that produce toxin even at low levels can be easily detected $(20,21)$. Thus, we used PCR assay for this purpose.

Staphylococcus aureus strains are widespread in hospitals and can be easily found on the surfaces and also internal space and can make a wide range of hospital infections including hospital acquired methicillin resistant $S$. aureus
(HA-MRSA) infections in patients (22). Therefore, determination of $S$. aureus strains prevalence in a hospital can be considered as an indicator for monitoring hospital health and hygiene status. High incidence of this agent in hospital environment indicates low healthcare efficiency.

Enterotoxin B and C were selected in our study, because they can be categorized in a subgroup of enterotoxins. In fact, SEB and the three isotypes of SEC (SEC1, SEC2 and SEC3) have nearly $70 \%$ identical at primary structure of proteins (amino acid sequence) leading to similar folding pattern and three-dimensional structure, eventually $(23,24)$.

On the other hand, enterotoxin $\mathrm{B}$ was chosen because of its importance in bioterrorism phenomenon as a bioweapon. Hence, this important macromolecule belongs to category $\mathrm{B}$ of bioterrorism agents and can easily through contaminated food causes food poisoning $(25,26)$. This toxin is rarely causing death and only high consumption can be fatal. However, high frequency of enterotoxin B-encoding $S$. aureus in a statistical society can be an alarm for a bioterrorism attack, especially in the Middle East that is important politically.

As previously mentioned, the majority of $S$. aureus isolates in dairy products encodes high level of SEC (16). Therefore by high presence SEC in a clinical sample, it seems that people have used the contaminated milk and this shows the importance of studying the enterotoxin C.

The results of current study revealed that from 60 detected S. aureus strains just 8 strains (13.3\%) possessed enterotoxin $\mathrm{B}$ and $\mathrm{C}$-producing genes. In addition, the prevalence of ent $B$ and ent $C$ is usually low in other research on enterotoxin genes frequency, while ent $A$ has usually high prevalence in among all the enterotoxins (27). Previously, Oliveira et al investigated enterotoxin production and enterotoxin gene distribution. Their results showed among the $83 \mathrm{~S}$. aureus isolated just 7 (8.4\%) isolates possess entC as well as entB genes was not identified (28).

Similar to our study, in 2015 a research was carried out on the prevalence of enterotoxin genes $S$. aureus isolated from animal originated foods that from $98 \mathrm{~S}$. aureus isolates examined, $4.1 \%$ and $5.1 \%$ carried entB and entC, respectively and as previously noted, entA was the most frequent (11).

Also in an Indian study in 2000 , both entB and entC had

Table 3. Clinical sample type, age range and gender of related by each of 8 entB and entC-encoding Staphylococcus aureus strains

\begin{tabular}{|c|c|c|c|c|}
\hline Positive sample & Number & Clinical samples type & Age range & Gender \\
\hline \multirow[t]{5}{*}{ entB } & 5 & Urine & Over 50 years & Man \\
\hline & & Urine & 20 years and under & Man \\
\hline & & Urine & $31-40$ years & Woman \\
\hline & & Nasal mucosa & 20 years and under & Man \\
\hline & & Blood & Over 50 years & Woman \\
\hline \multirow[t]{2}{*}{ entC } & 2 & Urine & Over 50 years & Woman \\
\hline & & Nasal mucosa & 20 years and under & Man \\
\hline entB \& entC & 1 & Wounds & 41-50 years & Man \\
\hline
\end{tabular}


low frequency $(5.6 \%$ and $7.5 \%$ respectively) (17) that confirms findings of present research.

In other study in 2011, detection of enterotoxin A, B, C and $Q$ genes was carried out, which in line with our findings, ent $B$ and $e n t C$ had nearly low prevalence by $15.8 \%$ and $9.5 \%$ respectively (29). In this research the abundance of ent $B$ is less than the ent $C$ that confirms our findings.

Like many studies, current study shows that some isolated S. aureus strains have more than one enterotoxin gene (30). Also, using statistical analysis we have examined the relationship between entB and entC-encoding $S$. aureus frequency and clinical samples type, the patient's age and patient's gender. Due to being $P$ value $\geq 0.05$ in all three statistical analysis, thus no correlation detected between the enterotoxin-encoding strains frequency and the three factors mentioned.

\section{Conclusion}

These results demonstrated that enterotoxin-producing strains have a relatively low incidence in clinical samples in one hospital of Ahvaz, but monitoring of their prevalence is necessary in regular screening programs in order to find the possible increase in their prevalence and prevention of their outcomes.

\section{Limitations of the study}

This study is a single center study, which further investigations by larger samples are needed.

\section{Authors' contribution}

Study concept and design; FN. Acquisition of data; HM. Laboratory work and analysis and interpretation of data; SA and AG.

\section{Conflicts of interest}

There is no conflict of interest regarding the publication of this paper.

\section{Ethical considerations}

Ethical issues (including plagiarism, misconduct, data fabrication, falsification, double publication or submission, redundancy) have been completely observed by the authors.

\section{Funding/Support}

This work was financially supported by the AJA University of Medical Sciences, Tehran, Iran.

\section{References}

1. Valihrach L, Alibayov B, Zdenkova K, Demnerova K. Expression and production of staphylococcal enterotoxin $\mathrm{C}$ is substantially reduced in milk. Food Microbiol. 2014; 44:54-9. doi: 10.1016/j.fm.2014.05.020.

2. Akineden O, Annemuller C, Hassan AA, Lammler C, Wolter W, Zschock M. Toxin genes and other characteristics of Staphylococcus aureus isolates from milk of cows with mastitis. Clin Diagn Lab Immunol. 2001; 8:959-64. doi: 10.1128/CDLI.8.5.959-964.2001.

3. Scallan E, Hoekstra RM, Angulo FJ, Tauxe RV, Widdowson MA, Roy SL, et al. Foodborne illness acquired in the United States--major pathogens. Emerg Infect Dis. 2011; 17:7-15. doi: 10.3201/eid1701.P11101.

4. Le Loir Y, Baron F, Gautier M. Staphylococcus aureus and food poisoning. Genet Mol Res. 2003; 2:63-76.
5. Wang K, Wu D, Chen Z, Zhang X, Yang X, Yang CJ, et al. Inhibition of the superantigenic activities of Staphylococcal enterotoxin A by an aptamer antagonist. Toxicon. 2016; 119:21-7. doi: 10.1016/j.toxicon.2016.05.006.

6. KimJ, Urban RG, StromingerJL, Wiley DC. Toxic shock syndrome toxin-1 complexed with a class II major histocompatibility molecule HLA-DR1. Science. 1994;266:1870-4.

7. Karp DR, Long EO. Identification of HLA-DR1 beta chain residues critical for binding staphylococcal enterotoxins $A$ and E. J Exp Med. 1992; 175:415-24.

8. Tarekgne EK, Skjerdal T, Skeie S, Rudi K, Porcellato D, Félix B, et al. Enterotoxin Gene Profile and Molecular Characterization of Staphylococcus aureus isolates from Bovine Bulk Milk and Milk Products of Tigray Region, Northern Ethiopia. J Food Prot. 2016; 79:1387-95. doi: 10.4315/0362-028X.JFP-16-003.

9. Corredor Arias LF, Luligo Espinal JS, Moncayo Ortiz J, Santacruz Ibarra JJ, Alvarez Aldana A. Relationship between super antigenicity, antimicrobial resistance and origin of Staphylococcus aureus isolated. Colomb Med (Cali). 2016; 47:15-20.

10. Varshney AK, Mediavilla JR, Robiou N, Guh A, Wang X, Gialanella $P$, et al. Diverse enterotoxin gene profiles among clonal complexes of Staphylococcus aureus isolates from the Bronx, NewYork. Appl Environ Microbiol. 2009; 75:68396849. doi: 10.1128/AEM.00272-09.

11. Mashouf RY, Hosseini SM, Mousavi SM, Arabestani MR. Prevalence of enterotoxin genes and antibacterial susceptibility pattern of Staphylococcus aureus strains isolated from animal originated foods in west of Iran. Oman Med J. 2015; 30:28390.

12. Pinchuk IV, Beswick EJ, Reyes VE. Staphylococcal enterotoxins. Toxins (Basel). 2010; 2:2177-97. doi: 10.3390/toxins2082177.

13. Schelin J, Wallin-Carlquist N, Cohn MT, Lindqvist R, Barker GC, Radström P. The formation of Staphylococcus aureus enterotoxin in food environments and advances in risk assessment. Virulence. 2011;2:580-92. doi: 10.4161/ viru.2.6.18122.

14. Ler SG, Lee FK, Gopalakrishnakone P. Trends in detection of warfare agents. Detection methods for ricin, staphylococcal enterotoxin B and T-2 toxin. J Chromatogr A. 2006;1133:1-12. doi: 10.1016/j.chroma.2006.08.078.

15. Valihrach L, Alibayov B, Demnerova K. Production of staphylococcal enterotoxin C in milk. Int Dairy J. 2013;30:1037. doi: 10.1016/j.idairyj.2013.01.003.

16. Fitzgerald JR, Monday SR, Foster TJ, Bohach GA, Hartigan PJ, Meaney WJ, et al. Characterization of a putative pathogenicity island from bovine Staphylococcus aureus encoding multiple superantigens. J Bacteriol. 2001;183:63-70. doi: 10.1128/ JB.183.1.63-70.2001.

17. Mehrotra M, Wang G, Johnson WM. Multiplex PCR for detection of genes for Staphylococcus aureus enterotoxins, exfoliative toxins, toxic shock syndrome toxin 1, and methicillin resistance. J Clin Microbiol. 2000;38:1032-5.

18. Shinagawa K, Watanabe K, Matsusaka N, Konuma H, Sugii $\mathrm{S}$. Enzyme-linked immunosorbent assay for detection of staphylococcal enterotoxins in incriminated foods and clinical specimens from outbreaks of food poisoning. Nippon J Uigaku Zasshi. 1990; 52:847-50.

19. Blaiotta G, Ercolini D, Pennacchia C, Fusco V, Casaburi A, Pepe $\mathrm{O}$, et al. PCR detection of staphylococcal enterotoxin genes in Staphylococcus spp. strains isolated from meat and dairy products. Evidence for new variants of seG and sel in S. aureus AB-8802. J Appl Microbiol. 2004; 97:719-30. doi: 10.1111/j.1365-2672.2004.02349.x.

20. Vernozy-Rozand C, Mazuy-Cruchaudet C, Bavai C, Richard Y. Comparison of three immunological methods for detecting staphylococcal enterotoxins from food. Lett Appl Microbiol. 2004;39:490-4. doi: 10.1111/j.1472-765X.2004.01602.x.

21. Cremonesi $P$, Luzzana $M$, Brasca $M$, Morandi S, Lodi $R$, Vimercati C, et al. Development of a multiplex PCR assay for 
the identification of Staphylococcus aureus enterotoxigenic strains isolated from milk and dairy products. Mol Cell Probes. 2005;19:299-305. doi: 10.1016/j.mcp.2005.03.002.

22. Lakshmi AV, Harasreeramulu S, Raju DVVS. Assessment of antibacterial potential of selected medicinal plants and their interactions with antibiotics on MRSA in the health care workers of Visakhapatnam hospitals. J Pharm Res. 2013;6:58992.

23. Papageorgiou AC, Achary KR, Shapiro R, Passalacqua EF, Brehm RD, Tranter HS. Crystal structure of the superantigen enterotoxin C2 from Staphylococcus aureus reveals a zincbinding site. Structure. 1995;3:769-79.

24. Swaminathan S, Furey W, Pletcher J, Sax M. Residues defining $\checkmark$ beta specificity in staphylococcal enterotoxins. Nat Struct Biol. 1995;2:680-6.

25. Ahanotu E, Alvelo-Ceron D, Ravita T, Gaunt E. Staphylococcal enterotoxin B as a biological weapon: recognition, management, and surveillance of staphylococcal enterotoxin. Appl Biosafety. 2006; 11:120-6.

26. Tilahun ME, Rajagopalan G, Shah-Mahoney N, Lawlor RG, Tilahun AY, Xie C, et al. Potent neutralization of staphylococcal enterotoxin $\mathrm{B}$ by synergistic action of chimeric antibodies.
Infect Immun. 2010; 78:2801-11. doi: 10.1128/IAI.01121-09.

27. Hait J, Tallent S, Melka D, Keys C, Bennett R. Prevalence of enterotoxins and toxin gene profiles of Staphylococcus aureus isolates recovered from a bakery involved in a second staphylococcal food poisoning occurrence. J Appl Microbiol. 2014; 117:866-75. doi: 10.1111/jam.12571.

28. Oliveira L, Rodrigues AC, Hulland C, Ruegg PL. Enterotoxin production, enterotoxin gene distribution, and genetic diversity of Staphylococcus aureus recovered from milk of cows with subclinical mastitis. Am J Vet Res. 2011; 72:1361-8. doi: 10.2460/ajvr.72.10.1361.

29. Saadati M, Barati B, Doroudian M, Shirzad H, Hashemi M, Hosseini SM, et al. Detection of sea, seb, sec, seq genes in Staphylococcus aureus isolated from nasal carriers in Tehran province, Iran; by multiplex PCR. J Paramed Sci. 2011; 2:3440 .

30. Omoe K, Ishikawa M, Shimoda Y, Hu DL, Ueda S, Shinagawa K. Detection of seg, seh, and sei genes in Staphylococcus aureus isolates and determination of the enterotoxin productivities of S. aureus isolates Harboring seg, seh, or sei genes. J Clin Microbiol. 2002;40:857-62. 